Article

\title{
Dysidinoid A, an Unusual Meroterpenoid with Anti-MRSA Activity from the South China Sea Sponge Dysidea sp.
}

\author{
Wei-Hua Jiao ${ }^{1, \dagger}$, Jing Li ${ }^{1,2, \dagger}$, Qian Liu ${ }^{3}$, Ting-Ting Xu ${ }^{1}$, Guo-Hua Shi ${ }^{1}$, Hao-Bing Yu ${ }^{4}$, \\ Fan Yang ${ }^{1}$, Bing-Nan Han ${ }^{1}$, Min $\mathrm{Li}^{3}$ and Hou-Wen Lin ${ }^{1,4, *}$
}

1 Key Laboratory for Marine Drugs, Department of Pharmacy, Renji Hospital, School of Medicine, Shanghai Jiaotong University, Shanghai 200127, China;

E-Mails: weihuajiao@hotmail.com (W.-H.J.); 120571114@163.com (T.-T.X);

shigh88804@hotmail.com (G.-H.S.); bill1985@126.com (F.Y.); bingnanh@hotmail.com (B.-N.H.)

2 College of Food and Biological Engineering, Jimei University, Xiamen 361021, China;

E-Mail: lijingjmu@163.com

3 Department of Clinical Laboratory, Renji Hospital, School of Medicine,

Shanghai Jiaotong University, Shanghai 200127, China; E-Mails: qq2005011@163.com (Q.L.); ruth_limin@126.com (M.L.)

4 Laboratory of Marine Drugs, Department of Pharmacy, Changzheng Hospital,

Second Military Medical University, Shanghai 200003, China; E-Mail: yuhaobing1986@126.com

$\dagger$ These authors contributed equally to this work.

* Author to whom correspondence should be addressed; E-Mail: franklin67@126.com; Tel.: +86-21-6838-3346; Fax: +86-21-5873-2594.

External Editor: Isabel C. F. R. Ferreira

Received: 19 October 2014; in revised form: 30 October 2014 / Accepted: 30 October 2014/

Published: 5 November 2014

\begin{abstract}
An unusual meroterpenoid, dysidinoid A (1), was isolated from the South China Sea sponge Dysidea sp. Its structure was elucidated by extensive spectroscopic methods including HRESIMS and 2D NMR, and its absolute configuration was determined by single-crystal X-ray diffraction analysis. Dysidinoid A (1) is the first meroterpenoid from Nature bearing a 9,4-friedodrime skeleton and a 2,5-dionepyrrole unit. Dysidinoid A (1) showed potent antibacterial activity against two strains of pathogenic bacteria methicillin-resistant Staphylococcus aureus (MRSA) with $\mathrm{MIC}_{90}$ values of $8.0 \mu \mathrm{g} / \mathrm{mL}$ against both.
\end{abstract}


Keywords: dysidinoid A; meroterpenoid; anti-MRSA; Dysidea; marine sponge

\section{Introduction}

Infectious diseases are the leading cause of death worldwide. Emerging infections due to methicillin resistant Staphylococcus aureus (MRSA) pose a significant threat to patients [1,2]. It has been estimated that in the United States more people die from MRSA related infections than from HIV [3]. Infections involving drug resistant bacteria are more difficult to treat due to increased costs and decreased efficacies [4,5]. One important approach to drug discovery for the treatment of MRSA is through natural products research.

Marine sponges of the genus Dysidea (order Dictyoceratida, family Dydideidae) have proven to be prolific producers of structurally diverse secondary metabolites, such as sesequiterpene quinones [6-8], sesquiterpenoids [9], diterpenoids [10], sterols [11], and polychlorinated compounds [12-14]. These metabolites showed a spectrum of interesting biological activities, including antifungal [15], antibacterial [16], antitumor [17,18], anti-inflammatory [15,19], and antioxidative activities [20].

In our efforts to search for new anti-MRSA agents from marine sponges collected from the South China Sea, chemical investigation of an active fraction from the sponge Dysidea sp. resulted in the isolation of a novel meroterpenoid, dysidinoid A (1) (Figure 1). It is the first meroterpenoid from Nature bearing a 9,4-friedodrime skeleton and a 2,5-dionepyrrole. Antibacterial evaluation showed that dysidinoid A showed potent antibacterial activity against two strains of pathogenic bacteria MRSA with $\mathrm{MIC}_{90}$ values of $8.0 \mu \mathrm{g} / \mathrm{mL}$ against both. Details of structural elucidation and antibacterial activity of dysidinoid A (1) were reported herein.

Figure 1. The chemical structure of dysidinoid A (1).

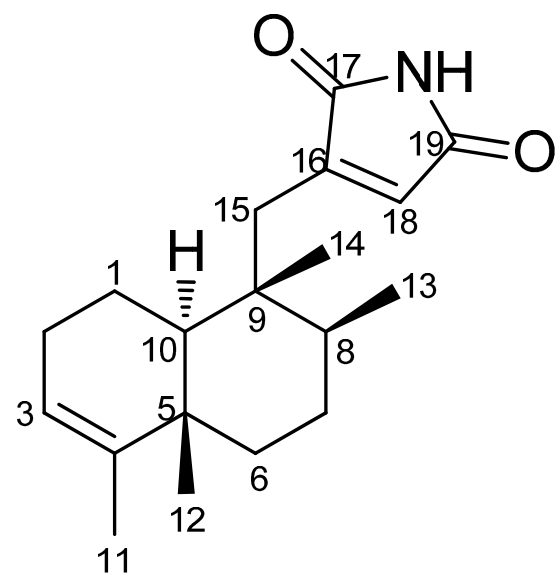

\section{Results and Discussion}

Dysidinoid A (1) was obtained as colorless needles with $[\alpha]_{\mathrm{D}}^{25}+35.4(c 0.50, \mathrm{MeOH})$. Its IR spectrum showed absorption bands assignable to amide $\left(3276 \mathrm{~cm}^{-1}\right)$ and carbonyl (1775 and 1714) functionalities. The positive ESIMS of 1 exhibited quasimolecular ion peaks at $m / z 302.2[\mathrm{M}+\mathrm{H}]^{+}$and $324.2[\mathrm{M}+\mathrm{Na}]^{+}$, respectively. The molecular formula of $\mathrm{C}_{19} \mathrm{H}_{27} \mathrm{NO}_{2}$ with seven degrees of 
unsaturation, was deduced from HRESIMS at $\mathrm{m} / z$ 324.1941 $[\mathrm{M}+\mathrm{Na}]^{+}$(calcd. for $\mathrm{C}_{19} \mathrm{H}_{27} \mathrm{NO}_{2}$, 324.1939), which was supported by the ${ }^{1} \mathrm{H}$ - and ${ }^{13} \mathrm{C}-\mathrm{NMR}$ data (Table 1 ). The ${ }^{1} \mathrm{H}-\mathrm{NMR}$ spectrum of 1 showed resonances attributable to two olefinic protons at $\delta \mathrm{H} 5.16(\mathrm{H}-3)$ and $6.26(\mathrm{H}-18)$, three tertiary methyl groups at $\delta_{\mathrm{H}} 1.55\left(\mathrm{H}_{3}-11\right), 1.00\left(\mathrm{H}_{3}-12\right)$, and $0.88\left(\mathrm{H}_{3}-14\right)$, a secondary methyl group at $\delta_{\mathrm{H}} 0.95$ $\left(\mathrm{H}_{3}-13\right)$. In addition, the spectrum showed resonances due to an exchangable amine proton at $\delta_{\mathrm{H}} 7.33$ $(20-\mathrm{NH})$, as well as partially overlapping signals with complex coupling patterns between $\delta_{\mathrm{H}} 1.08$ and 2.61 that could be attributed to several aliphatic methylene and methine units. The ${ }^{13} \mathrm{C}-\mathrm{NMR}$ and DEPT spectra of 1 showed 19 carbon resonances, corresponding to two carbonyl groups $\left(\delta_{\mathrm{C}} 171.7\right.$ and $170.4)$, two olefinic quaternary carbons $\left(\delta_{c} 143.9\right.$ and 147.9), two aliphatic quaternary carbons ( $\delta_{\mathrm{C}} 38.3$ and 42.4 ), two olefinic methine carbons ( $\delta_{\mathrm{C}} 120.5$ and 130.4$)$, two aliphatic methine carbons ( $\delta_{\mathrm{C}} 37.4$ and 47.0), five aliphatic methylene carbons $\left(\delta_{\mathrm{C}} 19.0,26.3,36.2,27.4\right.$, and 32.5), and four methyl carbons $\left(\delta_{\mathrm{C}} 17.7,19.8,16.3\right.$, and 18.0). The above spectroscopic signatures suggested the presence of a 9,4-friedodrime sesquiterpene moiety and accounted for four degrees of unsaturation, indicating three rings in the structure of $\mathbf{1}$.

Table 1. The ${ }^{1} \mathrm{H}-(600 \mathrm{MHz})$ and ${ }^{13} \mathrm{C}-(150 \mathrm{MHz}) \mathrm{NMR}$ data of compound $\mathbf{1}$ in $\mathrm{CDCl}_{3}$. ${ }^{\text {a }}$

\begin{tabular}{|c|c|c|c|c|}
\hline Position & $\delta_{\mathrm{C}}$ & $\delta_{\mathrm{H}}(J$ in $\mathrm{Hz})$ & HMBC $(\mathrm{H} \rightarrow \mathrm{C})$ & NOESY \\
\hline $1 \alpha$ & $19.0, \mathrm{CH}_{2}$ & $1.83, \mathrm{~m}$ & $\mathrm{C}-2,3,5,9,10$ & $\mathrm{H}-1 \beta, 2 \beta, 10$ \\
\hline $1 \beta$ & & $1.53, \mathrm{~m}$ & $C-2,5,10$ & $\mathrm{H}_{3}-12,14, \mathrm{H}-1 \alpha, 2 \beta$ \\
\hline $2 \alpha$ & $26.3, \mathrm{CH}_{2}$ & $1.93, \mathrm{~m}$ & & $\mathrm{H}-1 \alpha, 1 \beta, 10$ \\
\hline $2 \beta$ & & $2.07, \mathrm{~m}$ & $C-3,4,10$ & $\mathrm{H}-1 \alpha, 1 \beta, 2 \alpha$ \\
\hline 3 & $120.5, \mathrm{CH}$ & 5.16 , br s & $\mathrm{C}-5,11$ & $\mathrm{H}_{3}-11, \mathrm{H}-2 \alpha, 2 \beta$ \\
\hline 4 & $143.9, \mathrm{C}$ & & & \\
\hline 5 & $38.3, \mathrm{C}$ & & & \\
\hline $6 \alpha$ & $36.2, \mathrm{CH}_{2}$ & $1.08, \mathrm{~m}$ & $\mathrm{C}-8$ & H- $6 \beta, 7 \mathrm{a}, 8,10$ \\
\hline $6 \beta$ & & $1.68, \mathrm{dt}(12.8,3.4)$ & $\mathrm{C}-7,8,10,12$ & $\mathrm{H}_{3}-11,12, \mathrm{H}-6 \alpha, 7 \mathrm{~b}$ \\
\hline $7 \mathrm{a}$ & $27.4, \mathrm{CH}_{2}$ & $1.41, \mathrm{~m}$ & $C-5,6,9,13$ & H-6, 8 \\
\hline $7 b$ & & $1.40, \mathrm{dd}(6.9,3.5)$ & & $\mathrm{H}-6,8, \mathrm{H}_{3}-12,13,14$ \\
\hline 8 & $37.4, \mathrm{CH}$ & $1.28, \mathrm{~m}$ & $\mathrm{C}-7,9,13$ & $\mathrm{H}-7 \mathrm{~b}, 10, \mathrm{H}_{3}-13$ \\
\hline 9 & $42.4, \mathrm{C}$ & & & \\
\hline 10 & $47.0, \mathrm{CH}$ & $1.12, \mathrm{dd}(12.4,1.6)$ & $\mathrm{C}-2,4,5,9,12,14,15$ & $\mathrm{H}-1 \alpha, 2 \alpha, 8,15 \alpha, 15 \beta$ \\
\hline 11 & $17.7, \mathrm{CH}_{3}$ & 1.55, br s & $\mathrm{C}-3,4,5$ & $\mathrm{H}_{3}-12, \mathrm{H}-3$ \\
\hline 12 & $19.8, \mathrm{CH}_{3}$ & $1.00, \mathrm{~s}$ & $C-4,5,6,10$ & $\mathrm{H}_{3}-11,14, \mathrm{H}-6 \beta, 7 \beta$ \\
\hline 13 & $16.3, \mathrm{CH}_{3}$ & $0.95, \mathrm{~d}(6.7)$ & $\mathrm{C}-7,8,9$ & $\mathrm{H}_{3}-14, \mathrm{H}-7 \beta, 8$ \\
\hline 14 & $18.0, \mathrm{CH}_{3}$ & $0.88, \mathrm{~s}$ & $\mathrm{C}-8,9,10,15$ & $\mathrm{H}_{3}-12,13, \mathrm{H}-1 \beta, 7 \beta$ \\
\hline $15 \alpha$ & $32.5, \mathrm{CH}_{2}$ & $2.61, \mathrm{~d}(14.1)$ & $\mathrm{C}-8,9,10,14,16,17,18$ & $\mathrm{H}_{3}-14, \mathrm{H}-1 \alpha, 10$ \\
\hline $15 \beta$ & & $2.43, \mathrm{dd}(14.1,1.2)$ & $\mathrm{C}-8,9,10,14,16,17,18$ & $\mathrm{H}_{3}-13$ \\
\hline 16 & $147.9, \mathrm{C}$ & & & \\
\hline 17 & 171.7, C & & & \\
\hline 18 & $130.4, \mathrm{CH}$ & $6.26, \mathrm{~d}(1.0)$ & $\mathrm{C}-15,16,19$ & $\mathrm{H}_{3}-13, \mathrm{H}-10,15 \alpha, 15 \beta$ \\
\hline 19 & $170.4, \mathrm{C}$ & & & \\
\hline 20-NH & & 7.33, br s & & \\
\hline
\end{tabular}

${ }^{a}$ Assignments of the ${ }^{13} \mathrm{C}$ and ${ }^{1} \mathrm{H}$ signals were made on the basis of HSQC spectroscopic data.

Unambiguous assignment of NMR data of $\mathbf{1}$ was achieved by a combination of COSY, HSQC, and HMBC experiments, as depicted in Figure 2. In the ${ }^{1} \mathrm{H}-{ }^{1} \mathrm{H}$ COSY spectrum, the correlations of 
$\mathrm{H}_{2}-1 / \mathrm{H}_{2}-2 / \mathrm{H}-3, \mathrm{H}_{2}-6 / \mathrm{H}_{2}-7 / \mathrm{H}-8 / \mathrm{H}_{3}-13$, and allylic coupling correlations of $\mathrm{H}-3 / \mathrm{H}_{3}-11$ revealed the presence of two fragments (thick lines in Figure 2). The two spin systems and their connectivity with the remaining atoms enabled assembly into the final planar structure based upon the HMBC spectrum of 1. The HMBC correlations from $\mathrm{H}_{3}-11$ to $\mathrm{C}-3, \mathrm{C}-4$, and $\mathrm{C}-5$, from $\mathrm{H}_{3}-12$ to $\mathrm{C}-4, \mathrm{C}-5, \mathrm{C}-6$ and $\mathrm{C}-10$, from $\mathrm{H}_{3}-13$ to $\mathrm{C}-7, \mathrm{C}-8$, and $\mathrm{C}-9$, and $\mathrm{H}_{3}-14$ to $\mathrm{C}-8, \mathrm{C}-9, \mathrm{C}-10$, and $\mathrm{C}-15$ indicated the presence of 9,4-friedodrime sesquiterpene skeleton with four methyl groups at C-4, C-5, C-8, and C-9, respectively. This assignment was confirmed by the HMBC correlations from $\mathrm{H}-10$ to C-2, C-4, C-5, C-9, C-12, C-14, and C-15. Furthermore, the olefinic proton H-18 showed HMBC correlations with $\mathrm{C}-15, \mathrm{C}-16$, and $\mathrm{C}-19$, in combination with the chemical shifts of the proton and carbon resonances, suggested the presence of a 2,5-dionepyrrole substructure. In addition, $\mathrm{HMBC}$ correlations from the methylene protons $\mathrm{H}_{2}-15$ to $\mathrm{C}-8, \mathrm{C}-9$, C-10, C-14, C-16, C-17, and C-18 supported the linkage of C-9 and $\mathrm{C}-16$ via the methylene $\mathrm{CH}_{2}-15$ between the 9,4-friedodrime sesquiterpene moiety and 2,5-dionepyrrole substructure. Therefore, the gross structure of $\mathbf{1}$ was determined as shown in Figure 2.

Figure 2. Key COSY, HMBC, and NOESY correlations of dysidinoid A (1).
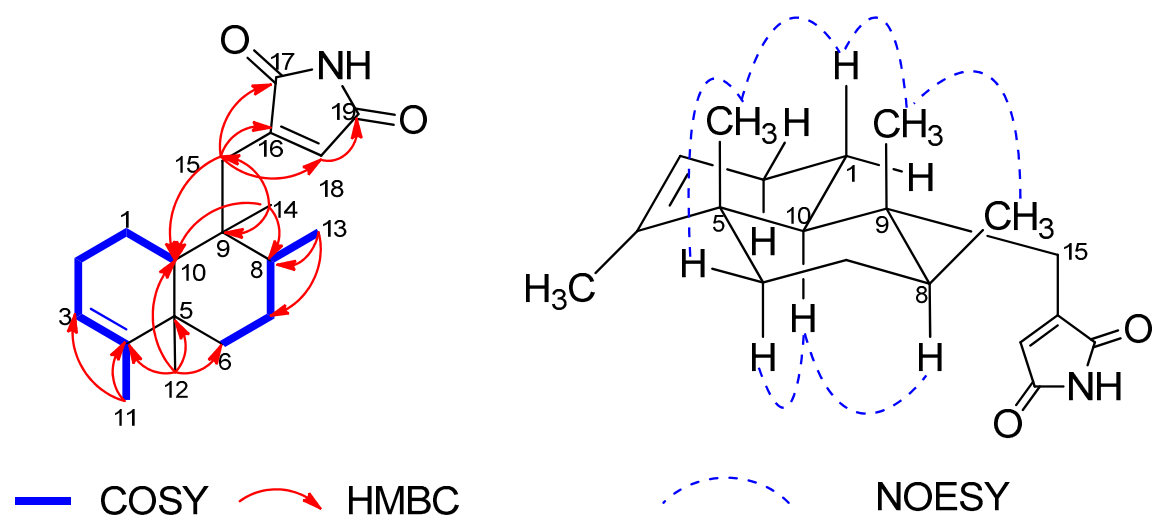

The relative configuration of $\mathbf{1}$ was deduced from NOESY correlations in combination with coupling constant values. The large coupling constant between $\mathrm{H}-1 \beta$ and $\mathrm{H}-10(J=12.4 \mathrm{~Hz})$ and the NOESY correlations of $\mathrm{H}-1 \beta / \mathrm{H}_{3}-12$ and $\mathrm{H}_{3}-14$ indicated the axial orientations of these protons and methyls and also revealed the trans fusion of the two six-numbered rings $[15,18]$. The NOESY correlation of $\mathrm{H}_{3}-13 / \mathrm{H}_{3}-14$ and $\mathrm{H}_{3}-12 / \mathrm{H}_{3}-14$ revealed the three methyl groups are all $\beta$-orientation, while NOESY correlations from $\mathrm{H}-8$ to $\mathrm{H}-6 \alpha$, and $\mathrm{H}-10$ suggested the three protons were $\alpha$-orientation.

Fortunately, crystals of $\mathbf{1}$ suitable for single crystal X-ray diffraction analysis were obtained from a methanol solution. The relative configuration of 1 was unambiguously established by its X-ray crystal structure (Figure 3). Besides, a final refinement of the $\mathrm{CuKa}$ diffraction data resulted in the assignment of the absolute configuration of $\mathbf{1}$ as $5 S, 8 S, 9 R$, and $10 S$.

Minimal inhibitory concentration (MIC) was detected to evaluate the antimicrobial activities of dysidinoid A (1) toward two strains of hospital-acquired methicillin-resitant Staphylococcus aureus (MRSA H0556 and MRSAH0117). Dysidinoid A (1) showed potent inhibitory activity against MRSA with $\mathrm{MIC}_{90}$ values of $8 \mu \mathrm{g} / \mathrm{mL}$, and chloromycetin was used as positive control ( $\mathrm{MIC}_{90} 2 \mu \mathrm{g} / \mathrm{mL}$ ), while methicillin was used as negative control (MIC90 $128 \mu \mathrm{g} / \mathrm{mL}$ ). 
Figure 3. X-ray ORTEP drawing of dysidinoid A (1).

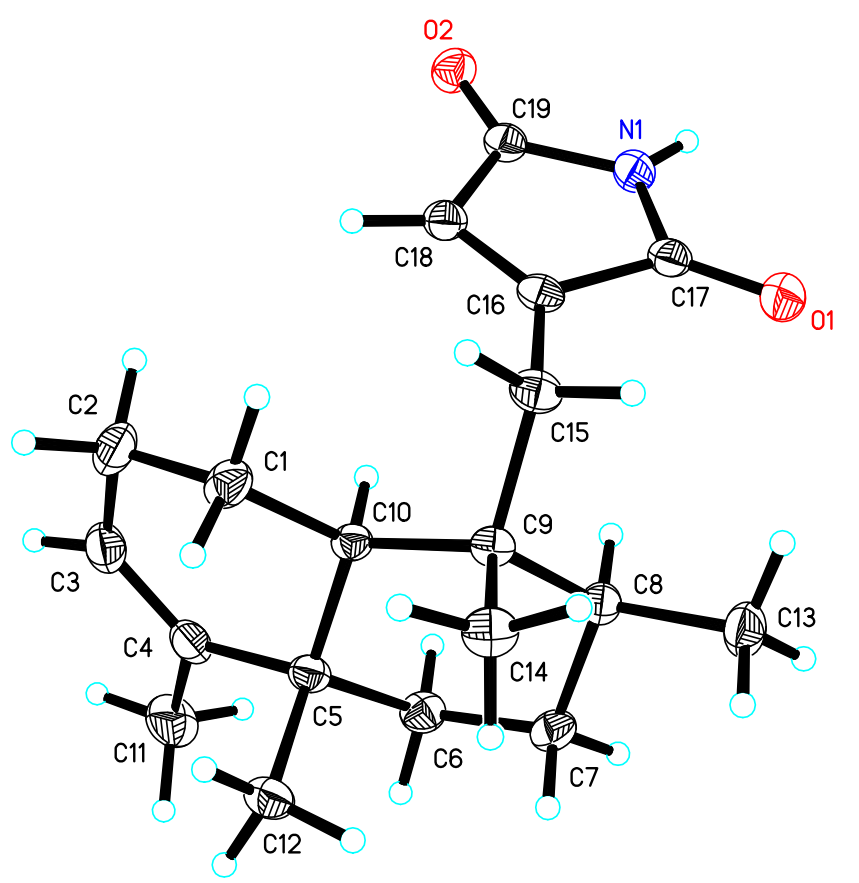

\section{Experimental Section}

\subsection{General Experimental Procedures}

Optical rotations were recorded on an Autopol I polarimeter (No. 30575, Rudolph Research Analytical, Perkin-Elmer, Inc., Waltham, MA, USA) with a $10 \mathrm{~cm}$ length cell at room temperature. UV and IR (KBr) spectra were recorded on a Hitachi U-3010 spectrophotometer (Hitachi, Inc., Tokyo, Japan) and Jasco FTIR-400 spectrometer (Jasco Inc., Tokyo, Japan), respectively. ${ }^{1} \mathrm{H},{ }^{13} \mathrm{C}$, DEPT135, COSY, HSQC, HMBC, and NOESY NMR spectra were recorded at room temperature on a Bruker Avance DRX-600 MHz NMR spectrometer ((Bruker Biospin Corp., Billerica, MA, USA) with $\mathrm{CDCl}_{3}$ as the solvent. HRESIMS spectra were measured on an Agilent 6210 LC/MSD TOF mass spectrometer (Agilent, Milford, MA, USA). Column chromatography was conducted using pre-coated silica gel $(65 \times 250$ or $230 \times 400$ mesh). Sephadex LH-20 was purchased from Amersham Pharmacia Biotech AB (Pharmacia Fine Chemicals, Piscataway, NJ, USA). Purification of the compounds was performed using a Waters Alliance 2695 separation module equipped with a Waters 2998 Photodiode Array (PDA) detector (Waters Corp., Milford, MA, USA).

\subsection{Animal Material}

Samples of Dysidea sp. were collected along the coast of Yongxing Island in Xiasha on 12 April 2010. The voucher number for this collection is XD10401, and a voucher sample is maintained at the Key Laboratory for Marine Drugs, Department of Pharmacy, Renji Hospital, School of Medicine, Shanghai Jiaotong University, Shanghai, China. The sponge was identified by Professor Jin-He Li (Institute of Oceanology, Chinese Academy of Science). 


\subsection{Extraction, Isolation and Characterization}

The animals (200 g, dry weight) were soaked in EtOH $\left(250 \mathrm{~mL}, 25{ }^{\circ} \mathrm{C}, 72 \mathrm{~h}\right)$ repeatedly to give $24.6 \mathrm{~g}$ of a crude EtOH extract after solvent removal. The extract was dissolved in $250 \mathrm{~mL} \mathrm{H}_{2} \mathrm{O}$, and partitioned five times with the same volume of $\mathrm{CH}_{2} \mathrm{Cl}_{2}$ to yield after concentration $12.0 \mathrm{~g}$ of a $\mathrm{CH}_{2} \mathrm{Cl}_{2}$ solvent extract, The $\mathrm{CH}_{2} \mathrm{Cl}_{2}$-soluble fraction was subjected silica gel column chromatography eluting with a gradient of $\mathrm{CH}_{2} \mathrm{Cl}_{2}$ and $\mathrm{MeOH}$, yielding four subfractions (D1-D4). Fraction D3 (1.4 g) was passed through an ODS chromatography column eluted with a gradient of aqueous $\mathrm{MeOH}$, size-exclusion chromatography Sephadex LH-20 eluted with $\mathrm{CH}_{2} \mathrm{Cl}_{2} / \mathrm{MeOH}(1: 1)$, and then purified by reversed-phase HPLC (YMC-Park Pro C18, $10 \mathrm{~mm} \times 250 \mathrm{~mm}, 2 \mathrm{~mL} / \mathrm{min}, 280 \mathrm{~nm}$ ) with $65 \% \mathrm{CH}_{3} \mathrm{CN}$, to give dysidinoid A (1, $\left.4.3 \mathrm{mg}, t_{\mathrm{R}} 26.5 \mathrm{~min}\right)$; colorless needles $(\mathrm{MeOH}) ;[\alpha]_{D}^{25}+35.4(c 0.5, \mathrm{MeOH})$; UV $(\mathrm{MeOH}) \lambda_{\max }(\log \varepsilon) 209$ (4.05), $235(398) \mathrm{nm} ;{ }^{1} \mathrm{H}$ and ${ }^{13} \mathrm{C}-\mathrm{NMR}$, see Table 1; IR (KBr) vmax 3276, 2961, 2928, 2857, 1775, 1714, 1621, 1453, 1344, 1124, 1075, 871, $626 \mathrm{~cm}^{-1}$; positive ESIMS $\mathrm{m} / z 302.2$ $[\mathrm{M}+\mathrm{H}]^{+}, 324.2[\mathrm{M}+\mathrm{Na}]^{+}$; positive HRESIMS $m / z 324.1941[\mathrm{M}+\mathrm{Na}]^{+}\left(\right.$calcd for $\left.\mathrm{C}_{19} \mathrm{H}_{27} \mathrm{NO}_{2}, 324.1939\right)$.

\subsection{X-ray Crystallographic Analysis of Dysidinoid A (1)}

$\mathrm{C}_{19} \mathrm{H}_{27} \mathrm{NO}_{2}$, colorless blocks, $M=301.42$, Orthorhombic, $P 2{ }_{1}, a=7.4098(2) \AA, b=14.0638(3) \AA$, $c=16.2014(3) \AA, \alpha=\beta=\gamma=90^{\circ}, V=1688.35(7) \AA^{3}, Z=4, D_{x}=1.186 \mathrm{mg} / \mathrm{m}^{3}, F(000)=656$, $\mu(\mathrm{Cu}-\mathrm{K} \alpha)=0.594 \mathrm{~mm}^{-1}$, crystal dimensions $0.30 \times 0.16 \times 0.10 \mathrm{~mm}^{3}$ were used for measurement on a SMART CCD using graphite monochromated radiation $(\lambda=1.54178 \AA)$; 5416 unique reflections were collected to $\theta_{\max }=69.73^{\circ}$. The structure was solved by direct methods (Shelxs97) and refined by full-matrix least-squares on $F^{2}$. Hydrogen atoms were located by the geometric calculation method and difference Fourier method. The final $R_{1}=0.0358, w R_{2}=0.1083\left(\mathrm{w}=1 / \sigma|\mathrm{F}|^{2}\right)$ and $S=1.012$. Crystallographic data for dysidinoid A (1) have been deposited with the Cambridge Crystallographic Data Center as supplementary publication No. CCDC 1029972. Copies of the data can be obtained, free of charge, on application to the Director, CCDC, 12 Union Road, Cambridge CB2 1EZ, UK (Fax:+44-(0)1223-336033, or E-Mail: deposit@ccdc.cam.ac.uk).

\subsection{Antimicrobial Assays}

Minimum inhibitory concentration (MIC) was determined according to Clinical and Laboratory Standards Institute (CLSI) guidelines. The MIC90 values were recorded using a spectrophotometer. For antibiotic sensitivity assays, bacteria in 96-well plates (Corning) were incubated with dysidinoid A (1) or antibiotic standards at final concentrations of 0 to $256 \mathrm{mg} / \mathrm{mL}$. The plates were incubated at $37^{\circ} \mathrm{C}$ and read at $24 \mathrm{~h}$.

\section{Conclusions}

Marine sponges provide a rich source on drug discovery for the treatment of MRSA infectious diseases. In this paper, dysidinoid A (1), an unusual meroterpenoid, was isolated from the South China Sea sponge Dysidea sp. Its structure was determined based on extensive spectroscopic data, and the absolute configuration of 1 was established by single-crystal X-ray diffraction analysis. Dysidinoid A (1) showed potent antibacterial activity against two strains of hospital-acquired pathogenic MRSA with MIC90 values of $8.0 \mu \mathrm{g} / \mathrm{mL}$ against both. 


\section{Supplementary Materials}

Supplementary materials can be accessed at: http:/www.mdpi.com/1420-3049/19/11/18025/s1.

\section{Acknowledgments}

This research was supported by the National Natural Science Fund for Distinguished Young Scholars of China (81225023), the Shanghai Rising-Star program (14QA1402800), the National Natural Science Fund of China (No. 41106127, 81302691, and 81172978), the Shanghai Subject Chief Scientist program (12XD1400200), the Fund of the Science and Technology Commission of Shanghai Municipality (14431901300), We are also grateful for the financial support of the National High Technology Research and Development Program of China (863 Projects, No. 2013AA092902).

\section{Author Contributions}

W.H.J. and J.L. contributed to the structural determination and manuscript writing. W.H.J. and T.T.X. conducted the isolation work for the new compound. J.L. and Q.L. performed the antimicrobial activity of the new compound against two strains of MRSA. G.H.S., H.B.Y., F.Y., B.N.H., M.L. gave the constructive suggestions for the experiments and manuscript writing. W.H.J. and H.W.L. conceived and designed the research.

\section{Conflicts of Interest}

The authors declare no conflict of interest.

\section{References}

1. Figueroa, M.; Jarmusch, A.K.; Raja, H.A.; El-Elimat, T.; Kavanaugh, J.S.; Horswill, A.R.; Cooks, R.G.; Cech, N.B.; Oberlies, N.H. Polyhydroxyanthraquinones as quorum sensing inhibitors from the guttates of penicillium restrictum and their analysis by desorption electrospray ionization mass spectrometry. J. Nat. Prod. 2014, 77, 1351-1358.

2. Li, T.; Song, Y.; Zhu, Y.; Du, X.; Li, M. Current status of Staphylococcus aureus infection in a central teaching hospital in Shanghai, China. BMC Microbiol. 2013, 13, doi:10.1186/1471-2180-13-153.

3. Payne, D.J. Desperately seeking new antibiotics. Science 2008, 321, 1644-1645.

4. Plaza, A.; Keffer, J.L.; Bifulco, G.; Lloyd, J.R.; Bewley, C.A. Chrysophaentins A-H, antibacterial bisdiarylbutene macrocycles that inhibit the bacterial cell division protein FtsZ. J. Am. Chem. Soc. 2010, 132, 9069-9077.

5. Li, M.; Du, X.; Villaruz, A.; Diep, B.; Wang, D.; Song, Y.; Tian, Y.; Hu, J.; Yu, F.; Lu, Y.; et al. MRSA epidemic linked to a quickly spreading colonization and virulence determinant. Nat. Med. 2012, 18, 816-819.

6. Jiao, W.H.; Xu, T.T.; Yu, H.B.; Chen, G.D.; Huang, X.J.; Yang, F.; Li, Y.S.; Han, B.N.; Liu, X.Y.; Lin, H.W. Dysideanones A-C, unusual sesquiterpene quinones from the South China Sea sponge Dysidea avara. J. Nat. Prod. 2014, 77, 346-350. 
7. Jiao, W.H.; Xu, T.T.; Yu, H.B.; Mu, F.R.; Li, J.; Li, Y.S.; Yang, F.; Han, B.N.; Lin, H.W. Dysidaminones $\mathrm{A}-\mathrm{M}$, cytotoxic and $\mathrm{NF}-\kappa \mathrm{B}$ inhibitory sesquiterpene aminoquinones from the South China Sea sponge Dysidea fragilis. RSC Adv. 2014, 4, 9236-9246.

8. Marcos, I.S.; Conde, A.; Moro, R.F.; Basabe, P.; Diez, D.; Urones, J.G. Quinone/hydroquinone sesquiterpenes. Mini-Rev. Org. Chem. 2010, 7, 230-254.

9. Ueda, K.; Kadekaru, T.; Siwu, E.R.; Kita, M.; Uemura, D. Haterumadysins A-D, sesquiterpenes from the Okinawan Marine sponge Dysidea c hlorea. J. Nat. Prod. 2006, 69, 1077-1079.

10. Lu, Q.; Faulkner, D.J. Three dolabellanes and a macrolide from the sponge Dysidea sp. from Palau. J. Nat. Prod. 1998, 61, 1096-1100.

11. De Almeida Leone, P.; Redburn, J.; Hooper, J.N. A.; Quinn, R.J. Polyoxygenated Dysidea sterols that inhibit the binding of [I125] IL-8 to the human recombinant IL-8 receptor type A. J. Nat. Prod. 2000, 63, 694-697.

12. Bai, R.; Paull, K.; Herald, C.; Malspeis, L.; Pettit, G.; Hamel, E. Halichondrin B and homohalichondrin $\mathrm{B}$, marine natural products binding in the vinca domain of tubulin. Discovery of tubulin-based mechanism of action by analysis of differential cytotoxicity data. J. Biol. Chem. 1991, 266, 15882-15889.

13. Fu, X.; Ferreira, M.L.G.; Schmitz, F.J.; Kelly-Borges, M. New diketopiperazines from the sponge Dysidea chlorea. J. Nat. Prod. 1998, 61, 1226-1231.

14. Kazlauskas, R.; Murphy, P.; Warren, R.; Wells, R.; Blount, J. New quinones from a dictyoceratid sponge. Aust. J. Chem. 1978, 31, 2685-2697.

15. Ciavatta, M.L.; Lopez Gresa, M.P.; Gavagnin, M.; Romero, V.; Melck, D.; Manzo, E.; Guo, Y.W.; van Soest, R.; Cimino, G. Studies on puupehenone-metabolites of a Dysidea sp.: Structure and biological activity. Tetrahedron 2007, 63, 1380-1384.

16. Urban, S.; Capon, R.J. 5-epi-Isospongiaquinone, a new sesquiterpene/quinone antibiotic from an Australian Marine sponge, Spongia hispida. J. Nat. Prod. 1992, 55, 1638-1642.

17. Pérez-García, E.; Zubía, E.; Ortega, M.J.; Carballo, J.L. Merosesquiterpenes from two sponges of the genus Dysidea. J. Nat. Prod. 2005, 68, 653-658.

18. Jiao, W.H.; Huang, X.J.; Yang, J.S.; Yang, F.; Piao, S.J.; Gao, H.; Li, J.; Ye, W.C.; Yao, X.S.; Chen, W.S.; et al. Dysidavarones A-D, new sesquiterpene quinones from the marine sponge Dysidea avara. Org. Lett. 2012, 14, 202-205.

19. McNamara, C.E.; Larsen, L.; Perry, N.B.; Harper, J.L.; Berridge, M.V.; Chia, E.W.; Kelly, M.; Webb, V.L. Anti-inflammatory sesquiterpene-quinones from the New Zealand sponge Dysidea cf. cristagalli. J. Nat. Prod. 2005, 68, 1431-1433.

20. Utkina, N.K.; Denisenko, V.A.; Krasokhin, V.B. Sesquiterpenoid aminoquinones from the marine sponge Dysidea sp. J. Nat. Prod. 2010, 73, 788-791.

Sample Availability: Sample of the compound $\mathbf{1}$ is available from the authors.

(C) 2014 by the authors; licensee MDPI, Basel, Switzerland. This article is an open access article distributed under the terms and conditions of the Creative Commons Attribution license (http://creativecommons.org/licenses/by/4.0/). 